\title{
Gender matters? How does gender shape risk environment for syringe sharing among people who inject drugs in northern Mexico. Results from a cross-sectional survey
}

\author{
Angélica Ospina-Escobar, ' Fátima Juárez²
}

\begin{abstract}
Programa de Política de Drogas, Centro de Investigación y Docencia Económica - Región Centro, Aguascalientes, México.

2 Centro de Estudios Demográficos, Urbanos y Ambientales, El Colegio de México, Ciudad de México, México.
\end{abstract}

\section{Correspondence:}

Angélica Ospina-Escobar

Programa de Política de Drogas, Centro de Investigación y Docencia Económica - Región Centro, Aguascalientes, México.

Circuito Tecnopolo Norte 117 , Col. Tecnopolo Pocitos II, 20313 Aguascalientes, México

Phone: 01449 994-5150 ext. 5239 Email: angelica.ospina@cide.edu

Received: 27 February 2019

Accepted: 12 August 2019

Citation:

Ospina-Escobar, A., \& Juárez, F. (2019). Gender matters? How does gender shape risk environment for syringe sharing among people who inject drugs in northern Mexico. Results from a cross-sectional survey. Salud Mental, 42(4), 165-172

DOI: $10.17711 /$ SM.0185-3325.2019.022

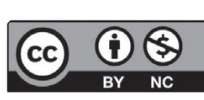

\begin{abstract}
Introduction. HIV prevalence among people who inject drugs (PWID) is $5 \%$. Studies have found a HIV prevalence around $10 \%$ among women who inject drugs (WWID) and $5 \%$ among men. Objective. To describe characteristics of risk environment that play different roles among men and women who inject drugs in Mexico that could be associated with those differentials. Method. In 2012 were interviewed in Hermosillo and Ciudad Juarez in places where population gathered. From them, 824 PWID $74.0 \%$ were men and $26.0 \%$ were women. Using chi-square test we analyzed associations of gender with demographics characteristics, drug use dynamics, and injecting behaviors. We fitted different generalized linear mixed models with random effects to test the hypothesis that predictors of receptive needle sharing have different effects on men and women. Results. Descriptive analysis showed that women live in conditions of higher vulnerability than men in terms of migration, educational attainment, occupation, and income. Women also reported a higher frequency of drug injection, a higher number of drugs used, and a higher prevalence of sharing needles. Variables significantly associated with the likelihood of sharing needles were: having being injected for someone else at first drug injection (adjusted odds ratio $[\mathrm{AOR}]=1.60,95 \%$ confidence interval $\mathrm{Cl}[1.11,2.25], p<.05$ ); injecting once a day or more $(A O R=1.80,95 \% \mathrm{Cl}[1.17,2.70], p<.05)$, using alcohol or drugs at least half of the time at their sexual encounters $(\mathrm{AOR}=1.64,95 \% \mathrm{Cl}[1.16,2.47], p<.05)$, experience of syringe confiscation by police (AOR = $1.54,95 \% \mathrm{Cl}[1.13,2.19], p<.05)$, and perceiving syringe availability as hard or very hard $(\mathrm{AOR}=2.29,95 \% \mathrm{Cl}$ $[1.49,3.32], p<.01)$. For women the most significant variable associated with syringe sharing was perception of syringe availability (AOR $=3.15,95 \% \mathrm{Cl}[1.25,7.91], p<.05)$, while for men was syringe confiscation by police $(\mathrm{AOR}=1.74,95 \% \mathrm{Cl}[1.20,2.50], p<.05)$. Discussion and conclusion. Results suggests the need to design and implement harm reduction programs that tackle the specific need of WID. Enhancing syringe availability through permanent harm reduction programs, implemented in coordination between public health authorities and community-based organizations, is a basic action to stop HIV spreading among PWID in northern Mexico, along with the decriminalization policies towards these population.
\end{abstract}

Keywords: Risk environment, people who inject drugs, gender, Mexico, harm reduction.

\section{RESUMEN}

Introducción. La prevalencia del VIH entre personas que se inyectan drogas (PIDs) es del 5\%. Los estudios han encontrado que la prevalencia del $\mathrm{VIH}$ es aproximadamente del $10 \%$ entre las mujeres que se inyectan drogas (MIDs) y del $5 \%$ entre los hombres. Objetivo. Este artículo busca describir detalladamente diferencias en las características que forman ambientes de riesgo diferenciados al $\mathrm{VIH}$ entre hombres y mujeres que se inyectan drogas en México. Método. Se entrevistó a 824 personas que se inyectan drogas (PIDs) en Hermosillo y Ciudad Juárez en 2012 en lugares de encuentro de población. El 74.0\% fueron hombres y el $26.0 \%$ mujeres. Mediante la prueba de chi-cuadrada, se caracterizan perfiles sociodemográficos, dinámicas de uso de drogas y de inyección por sexo. Se ajustan diferentes modelos lineales mixtos generalizados para probar la hipótesis que los predictores del uso compartido de jeringas tienen efectos distintos en hombres y mujeres. Resultados. El análisis descriptivo mostró que las mujeres viven en condiciones de mayor vulnerabilidad que los hombres en términos de migración, logros educativos, ocupación e ingresos. Las mujeres también informaron una mayor frecuencia de inyección de drogas, mayor número de drogas usadas y mayor prevalencia de uso compartido de jeringas. Las variables significativamente asociadas con la probabilidad de compartir jeringas fueron haber sido inyectado por alguien más al momento de la primera inyección (Razones de momios ajustadas $[A O R]=$ $1.60,95 \%$ intervalo de confianza IC [1.11, 2.25], $p<.05$ ), inyectarse una vez al día o más (AOR $=1.80,95 \%$ IC $[1.17,2.70], p<.05)$, consumir alcohol o drogas en al menos la mitad de sus encuentros sexuales $(A O R=1.64$, $95 \%$ IC $[1.16,2.47], p<.05)$, haber enfrentado confiscación de jeringas por parte de la policía (AOR = 1.54, 
$95 \%$ IC $[1.13,2.19], p<.05)$ y tener una mala percepción de la disponibilidad de jeringas (AOR $=2.29,95 \%$ IC $[1.49,3.32], p<.01$ ). Entre las mujeres, la variable más significativa asociado a la probabilidad de compartir jeringas fue la mala percepción de la disponibilidad de jeringas nuevas (AOR $=3.15,95 \%$ IC $[1.25,7.91], p<.05)$, mientras que en los hombres fue la experiencia de acoso policial $(A O R=1.74$, $95 \%$ IC [1.20, 2.50], $p<.05)$. Discusión y conclusión. Los resultados sugieren la necesidad de diseñar e implementar programas de reducción de daños que tomen en cuenta las necesidades específicas de las MIDs. Es urgente mejorar la disponibilidad de jeringas entre PWIDs en el norte de México por medio de programas permanentes de reducción de daños, implementados en coordinación entre las autoridades de salud pública y las organizaciones comunitarias y en conjunto con políticas de descriminalización de esta población.

Palabras clave: Ambiente de riesgo, personas que se inyectan drogas, género, México, reducción de daños.

\section{INTRODUCTION}

It is estimated that in Mexico there are around 56,000 people who inject drugs (PWID), half of which are allocated in the cities of Tijuana, Ciudad Juárez, and Hermosillo. In this population, it is estimated that $8 \%$ are women (UNAIDS, 2014). Although injected drugs do not have epidemic proportions, PWID are specially exposed to HIV and hepatitis $\mathrm{C}$, viruses that represent a high burden of disease for the Mexican health system.

Within PWID, several studies have shown the greater vulnerability women have for HIV and other health conditions, compared to their male counterparts. Brouwer et al., (2012) report an HIV prevalence among women who inject drugs (WWID) of $10.2 \%$, in contrast to $3.4 \%$ among men. Therefore, it is important to understand the role of gender in risk behaviors that facilitate the transmission of HIV and other blood-borne virus.

The higher HIV prevalence among WWID could be partly explained by the overlap between sex work and drug use networks (Sherman, Latkin, \& Gielen, 2001; Evans et al., 2003; Strathdee, Magis-Rodriguez, Mays, Jimenez, \& Patterson, 2012), in conjunction with the structural poverty conditions women face in Mexico (Patterson et al., 2006; Strathdee et al., 2008; Strathdee et al., 2013), and the highest exposure of WWID to violence (Beletsky et al., 2013; Syvertsen et al., 2014; West et al., 2016). In addition, the biologically transmission of HIV is more efficient from man to woman than vice versa (Strathdee \& Stockman, 2010).

There are few studies in Mexico that investigate the differentials in risk environments for HIV between men and women who inject drugs. The lack of data on the characteristics of the risk environments that are specifically addressed by the WWID and the processes through which these characteristics operate in the probabilities of getting infected make it difficult to incorporate a gender approach in the design of policies and harm reduction programs.

This article describes differences in the characteristics that build differentiated risk environments for HIV between men and women who inject drugs in Ciudad Juárez and Hermosillo.

\section{METHOD}

\section{Study design}

Data were collected between January and June 2012 in places that PWID were known to frequent (hotspots), following time-location-sampling methodology. The survey was supported by the Global Fund to Fight AIDS, tuberculosis and malaria (Round 9), and its aim was to evaluate HIV risk among PWID in Mexico's northern region.

\section{Participants}

Potential respondents were screened to verify if they met the eligibility criteria, being above 18 years old, reported having injected drugs at least once during the last three months, and reported being permanent residents of the selected cities. Screening began with the provision of general information about the study aims and procedures.

\section{Measurements}

We included in the analysis variables that correspond to the different domains outlined by the risk environment framework (Rhodes, 2002) which posits the need to shift from individualistic approaches of risk behavior towards an understanding of how structural and environmental conditions shape an individual's vulnerability to HIV acquisition. The focus of the analysis from this perspective is to identify social situations and places in which harm is produced and reduced. The risk environment is structured by interactions between domains (physical, social, economic, and political) and its different levels of influence (macro and micro) (Rhodes, 2002).

Following the risk environment framework, we included the city of residence and the gender as measures of the macrophysical and macrosocial domains, respectively. Age, migration status (born in the current city of residence $v s$. born anywhere else); level of educational attainment (completed secondary or more $v s$. partial secondary or less), and having a commercial sex partner during the last six months were included as measures of microsocial domain. We also 
included drug related variables within the microsocial domain of the risk environment such as type of fist illegal drug used. We used the variable CODAR, created by the Pan American Health Organization, to denote those substances that increase the risk of HIV such us cocaine, heroine, and methamphetamine (CODAR vs. no CODAR). Other drug related variables included within the microsocial domain were receiving assistance at firs drug injection (yes vs. no), frequency of drug injection (daily $v s$. less than daily), crystal-meth use during the last 12 months, and frequency of alcohol and drug use during their sexual encounters (less than half of the times $v s$. half of the times or more). Monthly income (less than 212 USD vs. more) was added for assessing the micro-economic domain. Micropolitical environment was assessed by variables related to interactions with criminal justice or public health institutions. These included: having experienced syringe confiscation by police during the last six months (yes vs. no), and perceived syringe/needle availability (based on responses to the question "In the last six months, how easy or hard was it for you to get new, unused syringes when you injected drugs?;" responses were dichotomized as "hard/very hard" vs. "easy/very easy").

For the outcome variable participants were considered to have participated in receptive needle sharing if they responded "sometimes," "often," or "always" to the question: "How often did you use a syringe that you knew or suspected had been used before by someone else?"

\section{Procedures}

Data were collected by trained interviewers who also had experience working with PWID. The survey includes a range of questions related to sociodemographic, sexual, and drug use risk behaviors, trajectories of drug use and treatment, exposure to health facilities, and other aspects of the physical and social risk environments that may increase the probability of HIV acquisition among participants.

\section{Statistical analyses}

Bivariate analyses were conducted to examine associations of gender and sociodemographic, behavioral, and context-related characteristics. We used chi square tests to compare proportions among men and women and Wilcoxon test for continuous variables. We then built generalized linear mixed models with random effects (GLMMIX) to identify factors independently associated with the odds of having receptive-sharing syringes practices in the past six months. As it is possible that observations within each city are correlated among each other, violating the assumption of independent observations, we use city of residence as a cluster variable in each model and we included random effects in the linear predictors as a mean to adjust the variance within and between cities.
As we want to test the hypothesis that independent variables play different roles on receptive-sharing needle, according with gender, interactions terms between all the predictors and sex were included in a second model assessed.

Then we built a we fitted a third GLMMIX stratified by sex and compared the outcomes between the models. Models were developed using an a priori design whereby variables with a significance level of $p<.1$ in univariate analysis were considered for inclusion in a multivariable model using the forward method. We analyzed multicollinearity between the predictor variables using the Pearson Correlation Test and we only included variables with a correlation lower than .3. We used the Hosmer and Lemeshow test to analyze the model's goodness of fit. The statistical analysis was run using STATA version 14.

\section{Ethical considerations}

Potential participants were asked for verbal consent before beginning the screening interview. Ineligible individuals were offered free condoms, information and referrals for HIV testing. All participants signed an informed consent form. The Institutional Review Boards of the UCSD School of Medicine and the Mexico' Instituto Nacional de Salud Pública (INSP) approved the study (Robertson et al., 2014).

\section{RESULTS}

There were 824 PWID surveyed, among which $74.0 \%$ were men and $26.0 \%$ were women. The sociodemographic profile of participants shows conditions of greater vulnerability for women in terms of migration, schooling, occupation, and income compared to men (Table 1). While almost 39\% of the women reported being migrant to the current city of residence, the proportion was about $23 \%$ among men $(p<.001)$. Most women reported a schooling attainment lower than completed secondary, while the proportion among men was almost $34 \%(p<.001)$. Women also reported much lower access to formal employment than men (7.0\% vs. 27.3\%, $p<.001$ ), even though Hermosillo and Ciudad Juárez have an important presence of maquilas, which hired mainly women. This could express that these women face an especially difficult situation to get incorporated into the local labor markets. Consequently, sex work appears as an important source of income for women but not for men $(35.6 \% v s .0 .15 \%, p<.001)$; however, their income level is lower than the one reported by men $(p<.05)$.

When comparing trajectories of illegal drug use (Table 2), data show that women initiated their drug use with cocaine, heroin, or methamphetamine in a higher proportion than men, which is associated with a faster transition to drug injection (Ospina-Escobar, 2018). Regarding the first injection of an illegal drug, most women $(90 \%)$ declared that 
Table 1

Sociodemographic characteristics of PWID by sex

\begin{tabular}{lcccc}
\hline & $\begin{array}{c}\text { Men } \\
(n=681)\end{array}$ & $\begin{array}{c}\text { Women } \\
(n=143)\end{array}$ & $\begin{array}{c}\text { All } \\
(N=824)\end{array}$ & $\begin{array}{c}\text { Statistical } \\
\text { differences }\end{array}$ \\
\hline Age (mean) & 35.7 & 34.5 & 35.4 & 42.62 \\
$\quad$ Migration (\%) & & & & \\
$\quad$ Immigrants to current city of residence & 22.9 & 38.7 & 25.6 & $15.36^{* * *}$ \\
Educational level (\%) & & & & \\
$\quad$ Uncomplete secondary school or less & 33.6 & 55.2 & 37.4 & $23.60^{* * *}$ \\
Main source of income (\%) & & & & \\
$\quad$ Formal employment & 27.3 & 7.0 & 23.8 & $261.79^{* * *}$ \\
$\quad$ Informal employment & 52.4 & 25.9 & 47.8 & \\
$\quad$ Drugs related activities & 3.8 & 2.1 & 2.9 & \\
$\quad$ Sex work & .1 & 35.6 & 6.3 & \\
Monthly Income & & & & \\
$\quad$ Until $\$ 3,500(\mathrm{MXP})$ & 55.3 & 63.0 & 56.6 & $2.80^{* *}$ \\
$\quad$ \$3,501 (MXP) or more & 44.7 & 37.0 & 43.4 & \\
\hline Note: ${ }^{* * *} p<.001 ;{ }^{* *} p<.1$. & & & & \\
\end{tabular}

someone had injected them, while the proportion among men was $68 \%(p<.001)$.

We found no differences on the type of drugs participants injected during last 12 months by sex, though women reported a slightly higher frequency of injection, which posit them in higher risk of blood infections and vein collapses (Table 2). On the other hand, women also reported a higher frequency of alcohol and drug use during their sexual encounters.

Regarding access to services and interaction with police, women reported a higher access to HIV testing, which could be associated to the local regulation of sex work in
Ciudad Juárez and Hermosillo, which impose them regular HIV testing at a cost. We found no significant differences by sex on the experience of syringe confiscation by police and access to treatment for drug abuse (Table 3 ).

These descriptive findings suggest that men and women face differential structural characteristics and distinct barriers to access health care services. Therefore, it is possible to think that predictors for receptive needle sharing have differential effects and weights on men and women.

To test this hypothesis, we fitted generalized linear mixed models with random effects (GLMMIX). The first one includes sex as a predictor of receptive needle sharing, the

Table 2

Characteristics of drug use among PWID by sex

\begin{tabular}{|c|c|c|c|c|}
\hline & $\begin{array}{c}\text { Men } \\
(n=681)\end{array}$ & $\begin{array}{l}\text { Women } \\
(n=143)\end{array}$ & $\begin{array}{c}A l l \\
(N=824)\end{array}$ & $\begin{array}{r}\text { Statistical } \\
\text { differences }\end{array}$ \\
\hline \multicolumn{5}{|l|}{ Trajectories of drug use } \\
\hline First illegal drug use was cocaine, heroin or methamphetamine (\%) & 17.2 & 27.7 & 19.0 & $8.32^{* *}$ \\
\hline Someone injected him/her at first injected drug use $(\%)^{* * *}$ & 67.6 & 90.2 & 71.5 & $29.77^{* \star *}$ \\
\hline Current dynamics of drug use & & & & .44 \\
\hline \multicolumn{5}{|l|}{ Drugs most commonly injected during last 12 months (\%) } \\
\hline Heroin & 87.5 & 89.5 & 87.9 & \\
\hline Cocaine/crack & 4.3 & 4.2 & 2.4 & \\
\hline Methamphetamine & 6.5 & 4.9 & 4.3 & \\
\hline Frequency of drug injection during last 12 months (\%) & & & & $6.27^{* *}$ \\
\hline Once a day or less & 21.0 & 11.9 & 19.4 & \\
\hline More than once a day & 79.0 & 88.1 & 80.6 & \\
\hline Use of alcohol or drugs at sexual encounters during last 6 months (\%) & & & & $668.88^{* * *}$ \\
\hline Less than half of the times & 28.3 & 16.1 & 26.2 & \\
\hline Half of the times or more & 71.7 & 83.9 & 73.8 & \\
\hline
\end{tabular}

Note: ${ }^{* * *} p<.001 ;{ }^{* *} p<.05$. 
Table 3

Access to health services and syringe confiscation by police officers among PWID

\begin{tabular}{lcccc}
\hline Contact with institutions & $\begin{array}{c}\text { Men } \\
(n=1118)\end{array}$ & $\begin{array}{c}\text { Women } \\
(n=376)\end{array}$ & $\begin{array}{c}\text { All } \\
(N=1494)\end{array}$ & $\begin{array}{c}\text { Statistical } \\
\text { differences }\end{array}$ \\
\hline Have ever received attention for problematic drug use (\%) & 73.0 & 73.2 & 73.0 & .004 \\
Have been ever tested for HIV (\%) & 48.8 & 63.6 & 51.3 & $10.55^{\star *}$ \\
Police has confiscated new syringes/needles (\%) & 41.1 & 35.2 & 40.1 & 1.69 \\
Perception of syringe availability as hard or very hard & 24.2 & 35.0 & 26.1 & $7.06^{* *}$ \\
\hline
\end{tabular}

Note: ${ }^{* *} p<.05$.

second one includes interactions between sex and selected predictors and the third one is stratified by sex (Table 4).

As shown in Table 4, factors related with characteristics of drug use and drug injection initiation have a strong positive association with receptive needle sharing. For example, those who were injected for someone else at first drug injection were $60 \%$ more likely to get engaged in receptive syringe sharing than those who injected themselves (adjusted odds ratio $[\mathrm{AOR}]=1.60,95 \%$ confidence interval CI [1.11, 2.25], $p<.05)$. As expected, those with higher frequency of drug injection are $80 \%$ more prone to share syringes than those that inject less than once a day $(\mathrm{AOR}=1.80,95 \% \mathrm{CI}[1.17,2.70], p<.05)$. Those who have used alcohol or drugs at least half of the time at their sexual encounters have 1.64 times more likelihood of sharing needles than those with lower frequency of drug or alcohol use while having sex $(\mathrm{AOR}=1.64$, $95 \%$ CI $[1.16,2.47], p<.05)$. On the other hand, duration between first illegal drug use and first injection shows a protective effect on the likelihood of syringe sharing as such, for each year of delay in first drug injection the odds of syringe sharing is reduce in $4 \%(\mathrm{AOR}=.96,95 \% \mathrm{CI}$ $[.93, .98], p<.05)$.

Political domain factors also shown significant and positive association with receptive syringe sharing. As such, participants who had experienced syringe confiscation by police during the prior six months are $54 \%$ more likely to share syringes sharing than those who haven't faced this police practice (AOR $=1.54,95 \% \mathrm{CI}[1.13,2.19], p<.05)$. Perceiving syringe availability as hard or very hard is also associated with higher proness to syringe sharing (AOR = $2.29,95 \%$ CI $[1.49,3.32], p<.01)$.

Gender appears as a significant factor associated with syringe sharing. The analysis indicates women have $43 \%$ less likelihood of having receptive syringe sharing practices compared to men $(\mathrm{AOR}=.57,95 \% \mathrm{CI}[.34, .89], p<.01)$. Even if this finding is interesting, it doesn't unravel which characteristics associated with the living conditions of gender play a role in the likelihood of syringe sharing among men and women. For that reason, we fitted a model with interaction terms between sex and selected characteristics of the risk environment.
The results from the second model, which includes interaction terms between sex and independent variables, indicates that adding interactive terms doesn't adds much to the models, as none of the selected variables were significantly associated with the likelihood of syringe sharing. However, as sex appears as a driver for syringe sharing, as in the first model, we run a stratified logistic model to test the hypothesis about the different effects that same predictors could have in the likelihood of syringe sharing. The stratified logistic analysis shows that while having an illegal occupation is not significantly associated with syringe sharing among women $(\mathrm{AOR}=2.97,95 \% \mathrm{CI}[.56,15.59]$, $p=.2)$, it is for men (AOR $=3.67,95 \%$ CI $[1.47,9.20], p$ $<.05)$. In terms of the political environment, the analysis shows that syringe confiscation by police is a factor associated with syringe sharing for men $(\mathrm{AOR}=1.74,95 \% \mathrm{CI}$ $[1.20,2.50], p<.05)$ but not for women $(\mathrm{AOR}=.91,95 \%$ CI [.38, 2.17], $p=.8)$.

Contrary to expected, having have commercial sex partner and having used alcohol or drugs during their sexual encounters are variable significantly associated with syringe sharing among men $(\mathrm{AOR}=1.88,95 \% \mathrm{CI}[1.06,3.33], p<$ $.05 ; \mathrm{AOR}=1.83,95 \% \mathrm{CI}[1.22,2.76], p<.05$ respectively), but not for women $(\mathrm{AOR}=1.68,95 \% \mathrm{CI}[.71,3.94], p=.2$; $\mathrm{AOR}=1.33,95 \% \mathrm{CI}[.42,4.25], p=.6$, respectively).

Duration time between first drug use and first drug injection, perception of syringe availability, and having received assistance at first drug injection have the same positive association with the likelihood of syringe sharing for men and women, but their weights seems to be higher among women, which could mean that for them a poor perception of syringe availability, shorter time between first drug use and first drug injection, and receiving assistance at first drug injection could have a stronger effect on the odds of receptive syringe sharing.

\section{DISCUSSION AND CONCLUSION}

The differential HIV prevalence reported in previous studies among men and women who inject drugs (Brouwer et al., 2012; Patterson et al., 2006) could respond to differen- 
Table 4

Multivariable analysis of factors associated with receptive needle sharing among PWID comparing by sex.

\begin{tabular}{|c|c|c|c|c|c|c|c|}
\hline \multirow[b]{3}{*}{ Female } & \multicolumn{7}{|c|}{ Adjusted odds ratio (95\% confidence intervals) } \\
\hline & \multirow{2}{*}{\multicolumn{2}{|c|}{$\begin{array}{c}\text { Model } \\
\text { without interactions } \\
.57^{* *}(.35-.92)\end{array}$}} & \multicolumn{2}{|c|}{$\begin{array}{c}\text { Model } \\
\text { with interactions }\end{array}$} & \multicolumn{2}{|c|}{ Only women } & \multirow[t]{2}{*}{ Only men } \\
\hline & & & 1.16 & $(.14-9.31)$ & & & \\
\hline Age & 1.00 & $(.99-1.03)$ & 1.01 & $(.99-1.03)$ & 1.00 & $(.96-1.07)$ & $1.01 \quad(.98-1.03)$ \\
\hline Secondary school & .93 & $(.63-1.37)$ & .90 & $(.60-1.33)$ & 1.28 & $(.52-3.19)$ & $.91 \quad(.57-1.34)$ \\
\hline Income above minimum wage & .89 & $(.63-1.26)$ & .91 & $(.63-1.28)$ & .74 & $(.30-1.72)$ & $1.01 \quad(.67-1.45)$ \\
\hline Illegal occupation & $3.46^{*}$ & * $(1.56-7.65)$ & $3.66^{* *}$ & $(1.48-9.17)$ & 2.96 & $(.55-15.29)$ & $3.63^{* *}(1.43-8.96)$ \\
\hline CODAR & .80 & $(.53-1.20)$ & .79 & $(.56-1.44)$ & .49 & $(.21-1.26)$ & $.90 \quad(.56-1.45)$ \\
\hline Someone injected him/her at first injection & $1.60^{* *}$ & * $(1.53-3.42)$ & $1.53^{*}$ & $(1.06-2.24)$ & $2.97^{*}$ & $(2.06-3.45)$ & $1.49^{* *}(1.03-2.17)$ \\
\hline $\begin{array}{l}\text { Duration (years) between first drug use and first } \\
\text { injection }\end{array}$ & $.96^{*}$ & * $(.93-.98)$ & $.96^{* *}$ & $(.93-.99)$ & $.93^{*}$ & $(.86-.98)$ & $.96^{* *}(.93-.99)$ \\
\hline Frequency of drug injection: Injects once a day or more & $1.80^{\star \star}$ & $*(1.18-2.74)$ & $1.91^{* *}$ & $(1.23-2.96)$ & 1.44 & $(.40-4.21)$ & $1.74^{\star *}(1.15-2.75)$ \\
\hline Have used crystal-meth during last month & 1.23 & $(.79-1.92)$ & 1.18 & $(.74-1.86)$ & 1.89 & $(.56-6.01)$ & $1.33 \quad(.84-2.05)$ \\
\hline $\begin{array}{l}\text { Perception of syringe availability: Hard or very hard } \\
\text { (vs. easy or very easy) }\end{array}$ & $2.29^{* *}$ & $*(1.53-3.42)$ & $2.13^{* *}$ & $(1.36-3.35)$ & $3.15^{\star}$ & $(1.31-4.33)$ & $1.92^{* *}(1.32-3.27)$ \\
\hline Have experienced syringe confiscation by police & $1.54^{* *}$ & * $(1.10-2.15)$ & $1.68^{* *}$ & $(1.17-2.42)$ & .91 & $(.38-2.15)$ & $1.73^{* *}(1.18-2.45)$ \\
\hline Have had commercial sex partner & $1.71^{* *}$ & * $(1.08-2.71)$ & $1.91^{* *}$ & $(1.08-3.39)$ & 1.67 & $(.71-3.94)$ & $2.05^{\star *}(1.06-3.31)$ \\
\hline Have used alcohol or drugs during sex encounters & $1.64^{* *}$ & $*(1.13-2.38)$ & $1.69^{* *}$ & $(1.16-2.49)$ & 1.33 & $(.39-3.88)$ & $1.83^{* *}(1.19-2.68)$ \\
\hline FemaleXillegal & & & .76 & $(.12-5.18)$ & & & \\
\hline FemaleXFreq_injec & & & .51 & $(.15-1.82)$ & & & \\
\hline FemaleXCODAR & & & .54 & $(.20-1.47)$ & & & \\
\hline FemaleXSyringe_Avail & & & 1.53 & $(.55-4.23)$ & & & \\
\hline FemaleXSyringe_Confis & & & .50 & $(.20-1.25)$ & & & \\
\hline FemaleXAssist_FirstInj & & & 2.13 & $(.57-7.88)$ & & & \\
\hline FemaleXCrys & & & 2.06 & $(.63-6.74)$ & & & \\
\hline FemaleXComSexPart & & & .75 & $(.27-2.05)$ & & & \\
\hline FemaleXduration & & & .97 & $(.90-1.04)$ & & & \\
\hline Constant & .68 & $(.25-1.84)$ & .62 & $(.21-1.75)$ & .149 & $(.23-2.85)$ & $.751(.22-2.12)$ \\
\hline Observations & & 793 & & 793 & & 135 & 658 \\
\hline Log likelihood & & -458.61 & & -455.30 & & -76.61 & -375.76 \\
\hline
\end{tabular}

Note: ${ }^{* *} p<.05 ;{ }^{*} p<.01$.

tiated risk environments enabled by the social construction of gender in Mexico.

In this paper, we explored some characteristics that could build different risk environments for men and women. Particularly, we found that institutional settings such as syringe availability and police practices are important drivers for syringe sharing but have differential effects on the likelihood of sharing needles among men and women. We also found that social settings such as sex work and dynamics of injection drugs initiation have different impact among men and women.

In terms of institutional settings, for women the variable that has a stronger significant association with the likelihood of receptive needles sharing is syringe availability, while for men it is police practices. Findings show that those women with the poorer perception of syringe availability had three times more likelihood of syringe sharing than those with more positive perception. Consequently, our data suggest that increasing access to sterile syringes is critical to addressing HIV risk among PWID in Mexico's northern region, especially among women.

Among men the combination of structural living conditions with police harassment and perception of insufficient syringe availability builds a risk environment that enables receptive syringe sharing. For example, syringe confiscation by police increases $82 \%$ the likelihood of receptive needle sharing, while working on an illegal context increases almost four times the likelihood of involvement in this risk behavior. Decriminalization of drug use and training of police forces are harm interventions that could address these components of risk environment among men.

In terms of social settings, involvement in sex work and using alcohol and drugs during sexual encounters are important predictors of syringe sharing among men but not among women. These could be associated with a higher stigmatization of male sex work and how it the limits up- 
take of healthcare services and their mental health (Crowell et al., 2017). Nevertheless, dynamics of transition to injecting drugs have stronger effect in the likelihood of sharing needles among women compared to men, as men often initiate women into injection and women used to have less skills about injection practices (Robertson et al., 2010).

Understanding how gender differences are associated with the dynamics of drug use is crucial to design specific interventions targeting men and women, but also transgender populations (Rusch et al., 2009). As women who inject drugs are more invisible, designing specific interventions for them is needed. This means to identify places where women who inject drugs gather and to penetrate in their social and sexual networks to distribute sterile equipment, rapid HIV test, and information, as well as addressing gender-based violence, as it is a factor associated with a higher prevalence of problematic drug use and risky injection practices (Jain et al., 2018).

In this paper, we show the importance of run differentiated analysis by sex in order to highlight how structural, biographical, institutional, and situational variables operate differentially for men and women who inject drugs. To recognize these differences and collect better data to follow up these findings is the first step to offer better services of harm reduction to people who inject drugs in Mexico aiming to reduce the gaps between men and women in a context of extreme vulnerability.

This paper has some limitations. Firstly, it is difficult to know to what extent the samples are representative of the broader population of PWID in the selected cities. As data were collected where PWID gathered, it is possible that the samples had higher levels of homogeneity among participants compared with the overall populations of PWID in each city. As such, findings cannot be generalized to the broader population of PWID in Mexico. Secondly, the sample was composed largely by men and it was not possible to oversample females as data were collected at places where PWID gather and these places use to be mainly inhabited by men, with scarce presence of women. To get more and better data for WID, it is needed to considerate specific sample strategies and try to oversample them to have a more robust comparison analysis with men data. We address these sample issues using a generalized mixed model, which allow us to take into account variability within-person and across-person variability, and thus, having more accurate estimations between men and women.

Thirdly, the cross-sectional nature of the survey data also limited our capacity to detect causal associations. As such, this study is restricted to highlighting the associative relationships between variables. More research is needed to identify the causal pathways and the complex set of relationships that influence syringe sharing and HIV prevalence among sampled PWID. Given the scarcity of data available, there is an urgent need to better understand the mechanisms of HIV spread among PWID in Mexico's northern region. These findings provide an important preliminary insight about how gender construction shapes different risk environments for men and women who inject drugs.

\section{Funding}

This research was supported by a grant (Round 9) from the Global Fund to Fight AIDS, Tuberculosis and Malaria (IMEX-901G01-H). Angelica Ospina-Escobar is supported by HIV Trust Scholarship Award (HIVRT15-100), the Sylff Research Abroad Award 2015, and CONACYT fellowship (2011-2012).

\section{Conflicts of interest}

The authors declare they have no conflicts of interest.

\section{REFERENCES}

Beletsky, L., Lozada, R., Gaines, T., Abramovitz, D., Staines, H., Vera, A., ... Strathdee, S. A. (2013). Syringe confiscation as an HIV risk factor: The public health implications of arbitrary policing in Tijuana and Ciudad Juarez, Mexico. Journal of Urban Health, 90(2), 284-298. doi: 10.1007/s11524-012-9741-3

Brouwer, K. C., Rusch, M. L., Weeks, J. R., Lozada, R., Vera, A., Magis-Rodríguez, C., \& Strathdee, S. A. (2012). Spatial epidemiology of HIV among injection drug users in Tijuana, Mexico. Annals of the Association of American Geographers. Association of American Geographers, 102(5), 1190-1199. doi: 10.1080/00045608.2012.674896

Crowell, T. A., Keshinro, B., Baral, S. D., Schwartz, S. R., Stahlman, S., Nowak, R. G., ... Ake, J. A. (2017). Stigma, access to healthcare, and HIV risks among men who sell sex to men in Nigeria. Journal of the International AIDS Society, 20(1), 21489. doi: 10.7448/IAS.20.01.21489

Evans, J. L., Hahn, J. A., Page-Shafer, K., Lum, P. J., Stein, E. S., Davidson, P. J., \& Moss, A. R. (2003). Gender differences in sexual and injection risk behavior among active young injection drug users in San Francisco (the UFO Study). Journal of Urban Health, 80(1), 137-146. doi: 10.1093/jurban/jtg137

Jain, J. P., Bristow, C. C., Pines, H. A., Harvey-Vera, A., Rangel, G., Staines, H., ... Strathdee, S. A. (2018). Factors in the HIV risk environment associated with bacterial vaginosis among HIV-negative female sex workers who inject drugs in the Mexico-United States border region. BMC Public Health, 18(1), 1032. doi: 10.1186/s12889-018-5965-9

Ospina-Escobar, A. (2018). Pistas para comprender el auge del VIH y drogas inyectadas en Hermosillo, Sonora. Aportes de la metodología mixta a la investigación demográfica. Coyuntura Demográfica, 13, 33-41. Retrieved from: http://www.somede.org/coyuntura-demografica/index.php/numero-13/ item/pistas-para-comprender-auge-vih-drogas-inyectadas-hermosillo-sonoraaportes-metodologia-mixta-investigacion-demografica

Patterson, T. L., Semple, S. J., Fraga, M., Bucardo, J., De La Torre, A., Salazar, J., ... Strathdee, S. A. (2006). Comparison of sexual and drug use behaviors between female sex workers in Tijuana and Ciudad Juarez, Mexico. Substance Use \& Misuse, 41(10-12), 1535-1549. doi: 10.1080/10826080600847852

Rhodes, T. (2002). The 'risk environment': A framework for understanding and reducing drug-related harm. International Journal of Drug Policy, 13(2), 85-94. doi: 10.1016/S0955-3959(02)00007-5

Robertson, A. M., Vera, A. Y., Gallardo, M., Pollini, R. A., Patterson, T. L., Case, P., ... Strathdee, S. A. (2010). Correlates of seeking injection assistance among injection drug users in Tijuana, Mexico. The American Journal on Addictions, 19(4), 357-363. doi: 10.1111/j.1521-0391.2010.00053.x

Robertson, A. M., Garfein, R. S., Wagner, K. D., Mehta, S. R., Magis-Rodriguez, C., Cuevas-Mota, J., ... Strathdee, S. A. (2014). Evaluating the impact of Mexico's drug policy reforms on people who inject drugs in Tijuana, BC, Mexico, and San Diego, CA, United States: A binational mixed methods research agenda. Harm Reduction Journal, 11(1), 4. doi: 10.1186/1477-7517-11-4

Rusch, M. L., Lozada, R., Pollini, R. A., Vera, A., Patterson, T. L., Case, P., \& Strathdee, S. A. (2009). Polydrug use among IDUs in Tijuana, Mexico: 
Correlates of methamphetamine use and route of administration by gender. Journal of Urban Health, 86(5), 760-775. doi: 10.1007/s11524-009-9377-0

Sherman, S. G., Latkin, C. A., \& Gielen, A. C. (2001). Social factors related to syringe sharing among injecting partners: a focus on gender. Substance Use \& Misuse, 36(14), 2113-2136. doi: 10.1081/JA-100108439

Strathdee, S. A., Lozada, R., Ojeda, V. D., Pollini, R. A., Brouwer, K. C., Vera, A., ... Patterson, T. L. (2008). Differential effects of migration and deportation on HIV infection among male and female injection drug users in Tijuana, Mexico. PloS One, 3(7), e2690. doi: 10.1371/journal.pone.0002690

Strathdee, S. A. \& Stockman, J. K. (2010). Epidemiology of HIV among injecting and non-injecting drug users: current trends and implications for interventions. Current HIV/AIDS Reports, 7(2), 99-106. doi: 10.1007/s11904-010-0043-7

Strathdee, S. A., Magis-Rodriguez, C., Mays, V. M., Jimenez, R., \& Patterson, T. L. (2012). The emerging HIV epidemic on the Mexico-US border: an international case study characterizing the role of epidemiology in surveillance and response. Annals of Epidemiology, 22(6), 426-438. doi: 10.1016/j.annepidem.2012.04.002
Strathdee, S. A., Abramovitz, D., Lozada, R., Martinez, G., Rangel, M. G., Vera, A., ... Patterson, T. L. (2013). Reductions in HIV/STI incidence and sharing of injection equipment among female sex workers who inject drugs: results from a randomized controlled trial. PloS One, 8(6), e65812. doi: 10.1371/journal. pone.0065812

Syvertsen, J. L., Robertson, A. M., Strathdee, S. A., Martinez, G., Rangel, M. G., \& Wagner, K. D. (2014). Rethinking risk: gender and injection drug-related HIV risk among female sex workers and their non-commercial partners along the Mexico-US border. International Journal of Drug Policy, 25(5), 836-844. doi: 10.1016/j.drugpo.2014.02.005

United Nations Programme on HIV/Aids (UNAIDS, 2014). The Gap Report. ISBN 978-92-9253-062-4

West, B. S., Abramovitz, D., Staines, H., Vera, A., Patterson, T. L., \& Strathdee, S. A. (2016). Predictors of injection cessation and relapse among female sex workers who inject drugs in two Mexican-US Border Cities. Journal of Urban Health, 93(1), 141-154. doi: 10.1007/s11524-015-9995-7 